

\section{Concentrations of Fecal Coliform Bacteria in Creeks, Anchorage, Alaska, August and September 1998}

By Joseph M. Dorava and Andra Love

U.S. GEOLOGICAL SURVEY

Open-File Report 99-236

Prepared in cooperation with the ALASKA DEPARTMENT OF ENVIRONMENTAL CONSERVATION 


\section{U.S. DEPARTMENT OF THE INTERIOR \\ BRUCE BABBITT, Secretary}

\section{U.S. GEOLOGICAL SURVEY}

Charles G. Groat, Director

Use of trade or firm names in this report is for identification purposes only and does not constitute endorsement

by the U.S. Geological Survey.

For additional information:

\section{District Chief}

U.S. Geological Survey 4230 University Drive, Suite 201

Anchorage, AK 99508-4664
Copies of this report may be purchased from:

U.S. Geological Survey

Branch of Information Services

Box 25286

Denver, CO 80225-0286

http://ak.water.usgs.gov 


\section{CONTENTS}

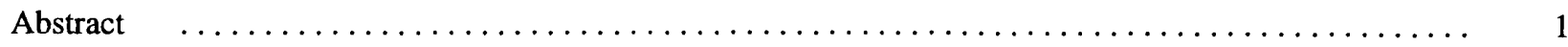

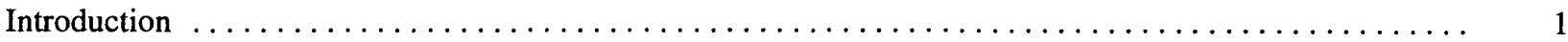

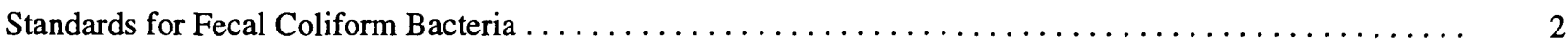

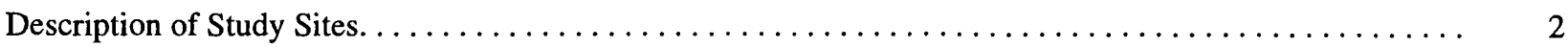

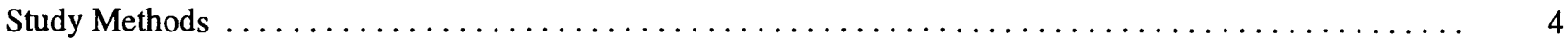

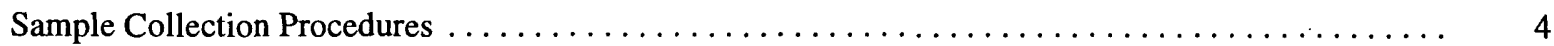

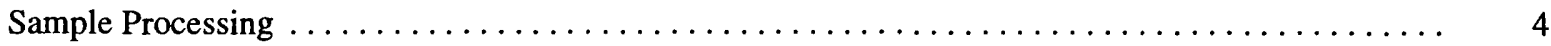

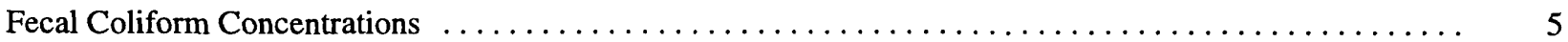

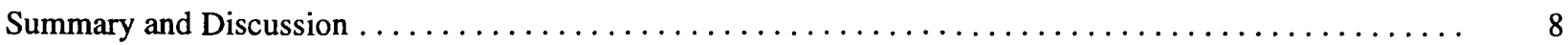

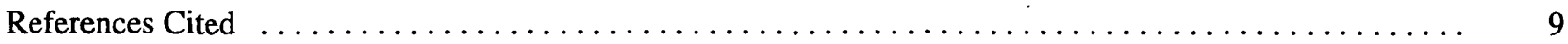

FIGURE

1. Map showing fecal indicator bacteria sampling sites in local creeks in Anchorage, Alaska ....... 3

\section{TABLES}

1. Fecal coliform concentrations in Anchorage creeks, $1988-92$ and $1998 \ldots \ldots \ldots \ldots \ldots \ldots \ldots$

2. Fecal coliform concentrations in Anchorage creeks, August and September $1998 \ldots \ldots \ldots \ldots \ldots .7$

3. Water-quality properties and stream discharge measured in Anchorage creeks during duplicate

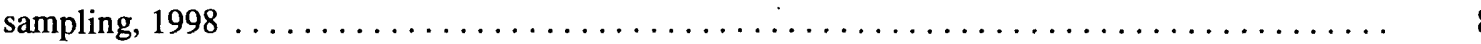

\section{CONVERSION FACTORS, WATER-QUALITY UNITS, AND VERTICAL DATUM}

\begin{tabular}{rll}
\hline Multiply & by & To obtain \\
\hline inch (in.) & 25.4 & millimeter \\
foot $(\mathrm{ft})$ & 0.3048 & meter \\
mile $(\mathrm{mi})$ & 1.609 & kilometer \\
cubic feet per second $\left(\mathrm{ft}^{3} / \mathrm{s}\right)$ & 0.02832 & cubic meter per second \\
& & \\
\hline
\end{tabular}

In this report, water temperature is reported in degrees Celsius $\left({ }^{\circ} \mathrm{C}\right)$, which can be converted to degrees Fahrenheit $\left({ }^{\circ} \mathrm{F}\right)$ by the following equation: ${ }^{\circ} \mathrm{F}=1.8\left({ }^{\circ} \mathrm{C}\right)+32$

\section{WATER-QUALITY UNITS}

$\mathrm{mL}$, milliliter

$\mathrm{col} / 100 \mathrm{~mL}$, fecal coliform colonies per 100 milliliters of water

$\mathrm{mg} / \mathrm{L}$, milligrams per liter

$\mu \mathrm{s} / \mathrm{cm}$, microsiemens per centimeter at 25 degrees Celsius

\section{VERTICAL DATUM}

Sea level: In this report, "sea level" refers to the National Geodetic Vertical Datum of 1929-A geodetic datum derived from a general adjustment of the first-order level nets of the United States and Canada, formerly called Sea Level Datum of 1929. 


\title{
Concentrations of Fecal Coliform Bacteria in Creers, Anchorage, Alaska, August and September 1998
}

\author{
By Joseph M. Dorava and Andra Love
}

\section{ABSTRACT}

Water samples were collected from five creeks in undeveloped, semi-developed, and developed areas of Anchorage, Alaska, during August and September 1998 to determine concentrations of fecal coliform bacteria. In undeveloped areas of Ship, Chester, and Campbell Creeks, and the semi-developed area of Rabbit Creek, concentrations of fecal coliform bacteria ranged from less than 1 to 16 colonies per 100 milliliters of water. In the semi-developed area of Little Rabbit Creek, concentrations ranged from 30 to 860 colonies per 100 milliliters of water. In developed areas of the creeks, concentrations of fecal coliform bacteria ranged from 6 to 80 colonies per 100 milliliters of water.

\section{INTRODUCTION}

Federal, State, and municipal agencies use fecal indicator bacteria to assess potential human health risks from waterborne diseases. Fecal indicator bacteria live in warm-blooded animals, and are typically introduced to surface water with animal and human wastes. Although they are not disease causing, the presence of fecal indicator bacteria in a water sample is correlated to the presence of several waterborne disease-causing organisms (pathogens). Because fecal indicator bacteria survive longer, occur in greater numbers, and are easier to test for than pathogenic bacteria, they are typically used as an acceptable measure of a water body's suitability for specific uses. The most widely used fecal indicator bacteria for the assessment of water bodies are fecal coliform.
Although fecal indicator bacteria commonly come from the intestines of warmblooded animals including man, they may also be associated with soils, vegetation, and insects. Because of the possibility of nonarimal sources, the occurrence of fecal coliform does not conclusively indicate fecal contamination.

From 1988 to 1992, the Municipality of Anchorage collected data on fecal coliform from numerous creeks (Municipality of Anchorage, unpublished data, 1999). On the basis of the data collected, five creeks (Ship, Chester, Campbell, Rabbit, and Little Rabbit Creeks) were included on the 303(d) "List of Water Quality-Limited Waterbodies" purlication (Alaska Department of Environmental Conservation, 1992), and have remained on this list through 1998 (ADEC, 1998). The unpublished data from the Municipality of Anchorage and several previous studies of creeks in Anchorage indicate that fecal coliform concentrations frequently exceaded ADEC standards and were highest during snowmelt and storm runoff periods (Brabets and Wittenberg, 1983; Brabets, 1987; James M. Montgomery Consulting Engineers Inc., 1990). There are, however, few comparable sets of data for undeveloped reaches of these creeks.

To address this lack of data, the U.S. Geological Survey (USGS), in cooperation with the ADEC, collected data to determine the fecal coliform concentration from undeveloped or semi-developed areas in the upper watersheds of five creeks in Anchorage. During an approximate 30-day period from August through September 1998, two to five samples were collected from undeveloped areas in the upper watersheds of each creek. One "check sample" 
was collected from a developed site in the lower watershed of each of these five creeks. The purpose of the check samples was to evaluate whether samples collected during August and September 1998 were significantly different from historical samples from the lower reaches. This report presents the results of the 1998 data-collection activity

\section{STANDARDS FOR FECAL COLIFORM BACTERIA}

Concentrations of fecal coliform bacteria in this report are expressed as the geometric mean of several samples and are reported as number of colonies per 100 milliliters of water $(\mathrm{col} / 100 \mathrm{~mL})$. For all potable waters, the detection of $1 \mathrm{col} / 100 \mathrm{~mL}$ may be cause for concern for public health (Myers and Wilde, 1997). In Alaska, the ADEC water-quality standards for a drinking-water supply state that in a 30-day period, the geometric mean of samples may not exceed $20 \mathrm{col} / 100 \mathrm{~mL}$, and not more than 10 percent of the samples may exceed $40 \mathrm{col} / 100$ $\mathrm{mL}$ (ADEC, 1999, p. 7). For water-contact recreation, the ADEC standards indicate that the geometric mean of samples collected during a 30-day period may not exceed $100 \mathrm{col} / 100 \mathrm{~mL}$ and not more than one sample, or more than 10 percent of the samples if there are more than 10 samples, may exceed $200 \mathrm{col} / 100 \mathrm{~mL}$ (ADEC, 1999, p. 7). The U.S. Environmental Protection Agency (1977) considers $200 \mathrm{col} / 100 \mathrm{~mL}$ an acceptable threshold for water contact recreation.

\section{DESCRIPTION OF STUDY SITES}

Ship, Chester, Campbell, Rabbit, and Little Rabbit Creeks were selected for sampling. All five originate at about 3,000 ft altitude in the Chugach Mountains and flow through the Anchorage lowlands to Cook Inlet. Each of these creeks has had elevated concentrations of fecal coliform bacteria (ADEC, 1992, 1998). The sampling sites in the upper parts of the Ship, Chester, and Campbell Creek watersheds (fig. 1) were considered to be in undeveloped areas for this study because there was little human impact upstream from the sites. The sampling sites in the upper parts of the Rabbit and Little Rabbit Creek watersheds were considered to be in semi-developed areas for this study because only single-family homes separated by large lots were upstream from the selected sampling sites. The sampling sites on the lower parts of the watersheds of all creeks were considered to be in developed areas for this study because the areas upstream consisted of high-density housing and commercial development. The lower sites were selected as closely as possible to the sites previously sampled by the Municipality of Anchorage, and reported in reports by Brabets and Witterberg (1983), Brabets (1987), and James M. Montgomery Consulting Engineers Inc. (1990).

Ship Creek: The sampling site for the upper watershed of Ship Creek (fig.1) is approximately $7 \mathrm{mi}$ upstream from the Glenn Highway and 9 mi upstream from urbarized areas. The upper site (not shown on figure 1) is accessed by a hiking trail that starts just before Arctic Valley Road terminates at Alpenglow Ski Area. The trail crosses Ship Creek, and four samples were collected about $10 \mathrm{ft}$ upst "eam from this trail crossing. About $0.5 \mathrm{mi}$ downstream from this site, two more samples were collected from a tributary to Ship Creek, about $10 \mathrm{ft}$ upstream from the trail. For this study, both these sites were considered as repre enting undeveloped areas of upper Ship Creek. The sampling site in the developed, lower watershed of Ship Creek is on the upstream side of a bridge where the creek crosses Reeve Boulevard (fig. 1).

Chester Creek: The sampling site in the upper part of Chester Creek (fig. 1) is on Fort Richardson about 3 mi upstream from Muldoon 


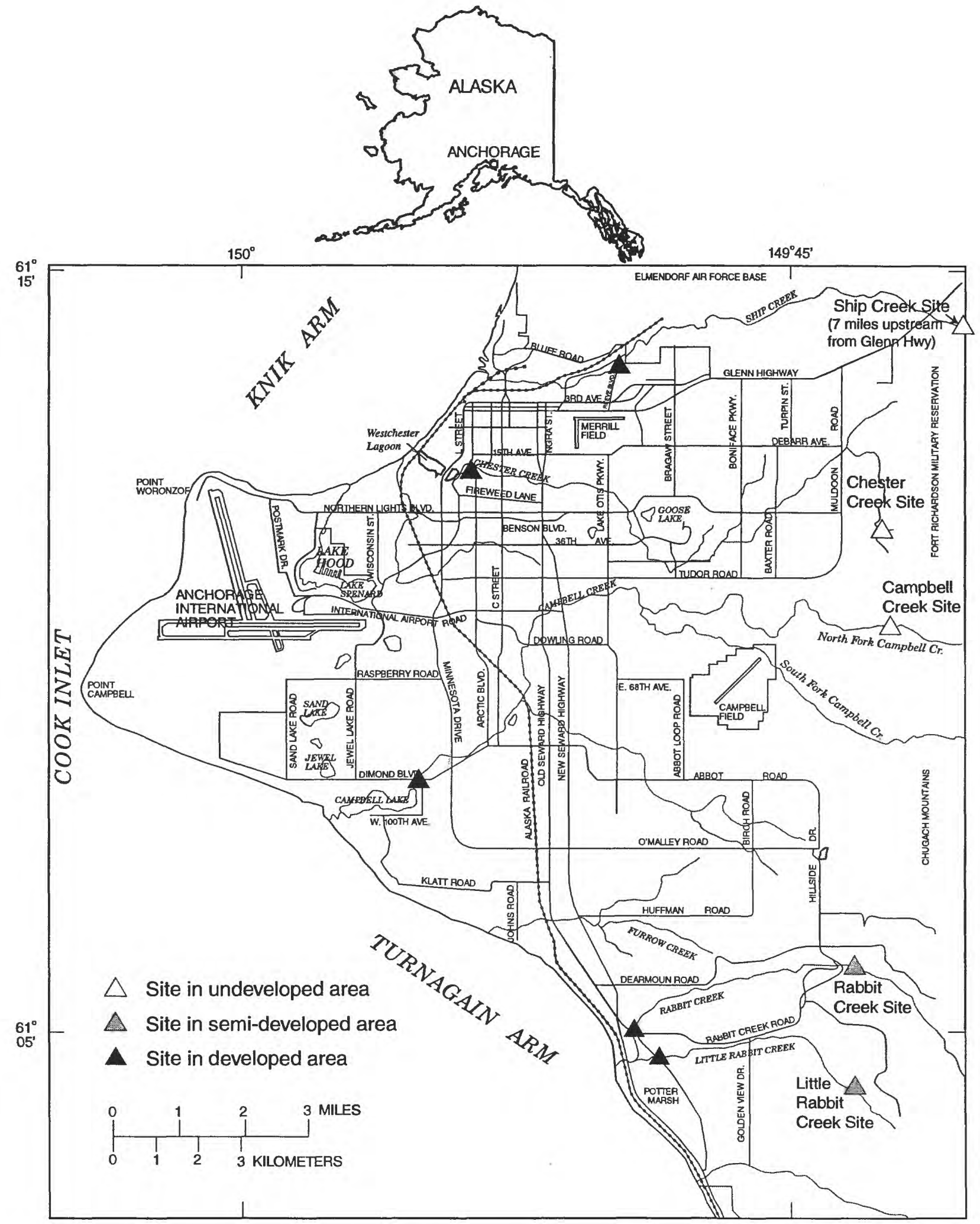

Figure 1. Fecal indicator bacteria sampling sites in local creeks in Anchorage, Alaska. 
Road. Only three samples were collected at this site because access was delayed by military permitting. The sampling site in the developed, lower part of Chester Creek is about $100 \mathrm{ft}$ downstream from the culvert where the creek crosses Arctic Boulevard (fig. 1).

Campbell Creek: The sampling site in the upper part of Campbell Creek is on the North Fork (fig. 1). Access to this sampling site is from Basher Road, which is east of Campbell Airstrip Road (not labeled on figure 1). At the end of Basher Road, a steep trail leads directly down to the creek. Water samples were collected at a site about $5 \mathrm{ft}$ upstream from this trail crossing. The sampling site in the developed, lower part of Campbell Creek is upstream from where the creek crosses Dimond Boulevard (fig. 1).

Rabbit Creek: The sampling site in the upper semi-developed part of Rabbit Creek is approximately $25 \mathrm{ft}$ upstream from where the creek crosses Hillside Drive (fig. 1). Although considerable recent development was evident upstream from the sampling site, it was selected for this study because access to sites farther upstream was limited, and data had been collected at this site in previous years. The sampling site in the developed, lower part of Rabbit Creek is upstream from where the creek crosses the Old Seward Highway (fig. 1).

Little Rabbit Creek: The sampling site in the upper, semi-developed part of Little Rabbit Creek (fig. 1) was about $50 \mathrm{ft}$ east of George Road, near the intersection of George Road and Nickleen Drive (not labeled on figure 1). Recent development also was evident upstream from this sampling site, but it too was selected for this study because access to sites farther upstream was limited, and data had been collected at this site in previous years. The sampling site in the developed, lower part of Little Rabbit Creek is at the Old Seward Highway (fig. 1).

\section{STUDY METHODS}

\section{Sample Collection Procedures}

Routine samples were taken according to methods prescribed by the American Public Health Association and others (1992). Sterile $100-\mathrm{mL}$ sample bottles were obtained and remained closed until the sample was taken. At a point equidistant from both banks, the bottle was placed top downward in the water approximately 6-12 in. from the surface, and then turned until the top pointed slightly upward in the direction of the streamflow. The cap was then removed and a water sample was collected. The cap was replaced and the bottle was removed from the water. Bottles were labeled with collector's name, date, time, site name, and bottle code. At each site, a single $100-\mathrm{mL}$ sample was collected and kept chilled until delivered to a commercial laborator:' in Anchorage.

A duplicate sample of water was also collected once at each undeveloped site. This duplicate sample of about $500 \mathrm{~mL}$ of water was collected using two sterile $250-\mathrm{mL}$ bottles and methods similar to those described above. Additionally, stream discharge, water temparature, specific conductance, $\mathrm{pH}$, and dissolvedoxygen concentrations were determined at each site during duplicate water sampling.

Sampling times were selected to sys'ematically collect samples during an approximate 30-day-long period without concern for dxcumenting specific flow regimes such as peck or low flows. Samples were collected once a reek from early August through the first week in September. The duplicate sample was collected at each site during the last site visit.

\section{Sample Processing}

Routine samples were processed by the Anchorage laboratory of Columbia Analytical Services, Inc. (CASI); duplicate samples were processed by USGS personnel. The time span from routine sample collection to delivery at 
the CASI laboratory did not exceed 24 hours. Holding times (the time span from collection to the beginning of incubation) for duplicate samples processed at the USGS laboratory did not exceed 6 hours. Holding times for routine samples processed at the CASI laboratory did not exceed 24 hours (Kim Tiplady, CASI analyst, oral commun., 1999).

Both CASI and USGS used in-house quality control/assurance procedures such as running a beginning blank and an ending blank, and using sterile buffered water for each sample. Fecal coliform concentrations were determined as the geometric mean using various sample volumes for duplicate samples. CASI also reported fecal concentrations as geometric means per $100 \mathrm{~mL}$ for the routine samples (Kim Tiplady, CASI analyst, oral commun., 1999).

All fecal coliform concentrations for this study were determined with the membrane-filter method (Myers and Wilde, 1997; American Public Health Association and others, 1992). In general, the water sample or a diluted sample of the water is filtered through a membrane filter using a low-pressure vacuum pump. The membrane filter is then placed in a petri dish filled with a nutrient-rich incubation medium. The bacteria in the water sample that are retained on the filter develop into visible colonies after incubation under specific conditions. For fecal coliform, these conditions include $24 \pm 2$ hours of growth at a temperature of $44.5 \pm 0.2{ }^{\circ} \mathrm{C}$ (Myers and Wilde, 1997). The visible colonies are then counted to provide a quantitative value of bacteria present in the sample volume tested. The concentration value reported is the geometric mean value per $100 \mathrm{~mL}$ of water, which is based on several sub-sample volumes with various colony counts for each sample. Under the best or "ideal" analytical conditions, counts would range from 20 to 60 colonies for each sample tested. For duplicate samples analyzed during this study, sample results were identified in those instances where non-ideal counting conditions existed (see table 2 later in this report). Geometric means can only be calcu- lated if all values are non-zero. For this renort, all reported values of zero and of "less than 1" were converted to 1 before the geometric mean was calculated. The geometric means were then rounded using standard engineering practice and reported to the nearest whole colony.

\section{FECAL COLIFORM CONCENTRATIC NS}

Ship Creek: The Municipality of Anchorage has numerous studies and data that provide historical information on fecal coliform concentrations in Ship Creek. For this report, a published subset (Montgomery-Watson Engineers, 1993) of these data was used. This subset consisted of 27 samples having a geometric mean concentration of $16 \mathrm{col} / 100$ $\mathrm{mL}$ (table 1). The samples were collected from three sites (Glenn Highway, Reeve Boulevard, and Post Road) during 1988-92. The geom?tric mean of six samples collected between August 6 and September 4, 1998, from the upper, undeveloped area was $2 \mathrm{col} / 100 \mathrm{~mL}$ (table 2). No individual samples had concentrations that were greater than the ADEC threshold of 40 col/ $/ 100 \mathrm{~mL}$. These concentrations were all within the ADEC threshold for water contact recreation.

The geometric mean of $2 \mathrm{col} / 100 \mathrm{~mL}$ of the six samples from the undeveloped reach is much less than both the $16 \mathrm{col} / 100 \mathrm{~mL}$ for the historical subset and $26 \mathrm{col} / 100 \mathrm{~mL}$ for the August-September historical subset (table 1). The single check sample from the developed area during the current study, however, was 7 $\mathrm{col} / 100 \mathrm{~mL}$ (table 2), which is also well below the geometric means of the historical values.

Chester Creek: Unpublished data from the files of the Municipality of Anchorage indicate that the mean concentration, based on 62 samples, in the developed lower reach of C'ester Creek was $442 \mathrm{col} / 100 \mathrm{~mL}$ (table 1). The check sample collected from the lower reach on September 4 was $80 \mathrm{col} / 100 \mathrm{~mL}$ (table 2). The 
Table 1. Fecal coliform concentrations in Anchorage creeks, 1988-92 and 1998 [Concentration in colonies per 100 milliliters of water]

\begin{tabular}{|c|c|c|c|c|c|c|}
\hline \multirow[b]{2}{*}{ Creek } & \multicolumn{4}{|c|}{ 1988-92 Municipality of Anchorage unpublished data } & \multicolumn{2}{|c|}{1998 USGS data } \\
\hline & $\begin{array}{c}\text { Geometric } \\
\text { mean } \\
\text { concentration }\end{array}$ & $\begin{array}{c}\text { No. of } \\
\text { samples }\end{array}$ & $\begin{array}{l}\text { August/ } \\
\text { September } \\
\text { geometric } \\
\text { mean } \\
\text { concentration }\end{array}$ & $\begin{array}{c}\text { No. of } \\
\text { samples }\end{array}$ & $\begin{array}{c}\text { August/ } \\
\text { September } \\
\text { geometric } \\
\text { mean } \\
\text { concentration }\end{array}$ & $\begin{array}{c}\text { No. of } \\
\text { samples }\end{array}$ \\
\hline Ship Creek & 16 & 27 & 26 & 6 & 3 & 6 \\
\hline Chester Creek & 442 & 62 & 695 & 18 & 6 & 3 \\
\hline Campbell Creek & 55 & 370 & 47 & 68 & 3 & 6 \\
\hline Rabbit Creek & 25 & 56 & 53 & 18 & 8 & 6 \\
\hline Little Rabbit Creek & 111 & 249 & 257 & 67 & 270 & 6 \\
\hline
\end{tabular}

geometric mean of three samples collected between August 19 and September 4 from the upper, undeveloped reach was $5 \mathrm{col} / 100 \mathrm{~mL}$, and no sample exceeded $40 \mathrm{col} / 100 \mathrm{~mL}$. Although the $80 \mathrm{col} / 100 \mathrm{~mL}$ in the check sample is well below the historical average of 442 $\mathrm{col} / 100 \mathrm{~mL}$, both the check sample and the historical data indicate a large difference in fecal coliform concentrations between the developed and undeveloped reaches.

Campbell Creek: Unpublished data from the Municipality of Anchorage indicate that 370 samples collected for the lower, developed reach have yielded an average of 55 $\mathrm{col} / 100 \mathrm{~mL}$ (table 1). The check sample collected on September 5 from the developed reach was $68 \mathrm{col} / 100 \mathrm{~mL}$ (table 2), which is near this historical average. Five samples collected from the upper, undeveloped reach between August 5 and September 5, however, averaged only $2 \mathrm{col} / 100 \mathrm{~mL}$. A very significant difference in concentrations of fecal coliform bacteria seems to exist between the developed and undeveloped areas.
Rabbit Creek: According to Municipal files, 56 samples from the lower, developed part of the creek averaged $25 \mathrm{col} / 100 \mathrm{~mL}$ (table 1). The check sample collected on September 5 contained $12 \mathrm{col} / 100 \mathrm{~mL}$ (table 2). The five samples collected from the semi-developed area between August 5 and September $5 \mathrm{rad}$ a geometric mean of $6 \mathrm{col} / 100 \mathrm{~mL}$. Although 6 $\mathrm{col} / 100 \mathrm{~mL}$ for the semi-developed area appears to be significantly less than the longterm mean for the lower watershed, $25 \mathrm{col} / 100$ $\mathrm{mL}$, this conclusion is not valid. The check sample for the developed area during the 1998 field season was $12 \mathrm{col} / 100 \mathrm{~mL}$, which was within the range of values for the semi-developed area and significantly lower than the historical values. The observed differences may be caused by geographic, temporal, or other factors.

Little Rabbit Creek: Municipal files indicate that 249 samples have been collected from the developed part of the creek. These samples averaged $111 \mathrm{col} / 100 \mathrm{~mL}$ (table 1). The check sample collected from this same reach on September 5 contained $68 \mathrm{col} / 100 \mathrm{~mL}$ 
Table 2. Fecal coliform concentrations in Anchorage creeks, August and September 1998

[col/100 mL, colonies per 100 milliliters of water]

\begin{tabular}{|c|c|c|c|c|c|}
\hline \multirow{2}{*}{ Date } & \multicolumn{2}{|c|}{$\begin{array}{l}\text { Fecal coliform concentration } \\
(\operatorname{col} / 100 \mathrm{~mL})\end{array}$} & \multirow{2}{*}{ Date } & \multicolumn{2}{|c|}{$\begin{array}{l}\text { Fecal coliform concentration } \\
(\text { (coV100 mL) }\end{array}$} \\
\hline & $\begin{array}{l}\text { Undeveloped } \\
\text { site }\end{array}$ & $\begin{array}{l}\text { Developed } \\
\text { site }\end{array}$ & & $\begin{array}{l}\text { Semi-developed } \\
\text { site }\end{array}$ & $\begin{array}{l}\text { Developed } \\
\text { site }\end{array}$ \\
\hline \multicolumn{3}{|c|}{ Ship Creek } & \multicolumn{3}{|c|}{ Rabbit Creek } \\
\hline August 6 & 6 & & August 5 & $<1$ & \\
\hline August 11 & $<1$ & & August 10 & 6 & \\
\hline August 17 & 2 & & August 17 & 8 & \\
\hline August 27 & 2 & & August 28 & ${ }^{a} 6$ & \\
\hline September 4 & $a_{2}$ & ag & August 28 & 14 & \\
\hline September 4 & 2 & 6 & September 5 & 16 & 12 \\
\hline Geometric mean & 2 & 7 & Geometric mean & 6 & \\
\hline \multicolumn{3}{|c|}{ Chester Creek } & \multicolumn{3}{|c|}{ Little Rabbit Creek } \\
\hline August 19 & 2 & & August 5 & 30 & \\
\hline September 4 & ${ }^{a_{7}}$ & & August 10 & 350 & \\
\hline September 4 & 10 & 80 & August 17 & 860 & \\
\hline Geometric mean & 5 & & August 28 & ${ }^{a} 160$ & \\
\hline \multicolumn{3}{|c|}{ Campbell Creek } & August 28 & 100 & \\
\hline August 5 & 6 & & September 5 & 120 & 68 \\
\hline August 11 & 6 & & Geometric mean & 161 & \\
\hline August 17 & 2 & & & & \\
\hline August 28 & $a^{a}<1$ & & & & \\
\hline August 28 & $<1$ & & & & \\
\hline September 5 & 2 & 68 & & & \\
\hline Geometric mean & 2 & & & & \\
\hline
\end{tabular}

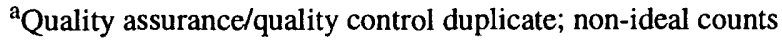

(table 2). Five samples collected from the semideveloped reach during August 5 to September 5 had a geometric mean of $161 \mathrm{col} / 100 \mathrm{~mL}$. The mean of $161 \mathrm{col} / 100 \mathrm{~mL}$ is biased by two very high values on August 10 and 17, during which time there were no comparable values for the developed reach. The August 10 and 17 values may represent a temporal change that may also have occurred but was undetected in the lower reach. The apparent conclusion that the mean concentration in the upper watershed (161 $\mathrm{col} / 100 \mathrm{~mL}$ ) is greater than the mean corcentration in the lower watershed $(111 \mathrm{col} / 100 \mathrm{~mL})$ is tenuous (table 1). 


\section{SUMMARY AND DISCUSSION}

In four of the five Anchorage creeks (Ship, Chester, Campbell, Rabbit) tested during this study, the concentration of fecal coliform was less than the State's threshold for drinkingwater supply $(20 \mathrm{col} / 100 \mathrm{~mL})$. In Little Rabbit Creek, however, the concentration of fecal coliform exceeded the threshold for drinking water in every sample and exceeded the threshold for water-contact recreation $(200 \mathrm{col} / 100$ $\mathrm{mL}$ ) in two samples.

The expected result of fecal coliform bacteria sampling along each creek was that concentrations would be substantially higher at the developed sites than at the undeveloped and semi-developed sites. Fecal coliform bacteria concentrations were higher at the developed sites than at the undeveloped sites for same-day samples on Ship Creek, Chester Creek, and Campbell Creek. In contrast, the concentration of fecal coliform bacteria was lower at the developed sites than at the semi-developed sites for same-day samples on Rabbit Creek and Little Rabbit Creek.

For Ship, Chester, and Campbell Creeks, concentrations of fecal coliform on September
4 and 5 were lower at the undeveloped sites than they were at the developed sites. For Rabbit and Little Rabbit Creeks, however, concentrations of fecal coliform on September 5 were higher at the semi-developed site than they were at the developed site (table 2).

At the developed sampling sites, Ship Creek and Rabbit Creek had mean concentrations of fecal coliform less than the 20 $\mathrm{col} / 100 \mathrm{~mL}$ water-quality standard for drinking-water supply. However, the concentration of fecal coliform at the developed sampling sites on Chester, Campbell, and Little Rabbit Creeks $(80,68$, and $68 \mathrm{col} / 100 \mathrm{~mL}$, respectively; table 2) each exceeded the 20 $\mathrm{col} / 100 \mathrm{~mL}$ water-quality standard for drinking-water supply. All samples collected had mean concentrations of fecal coliform that were lower than the ADEC standard for watercontact recreation.

In addition to the measurements of fecal coliform bacteria, selected water-quality froperties and stream discharge were measured (table 3) during the duplicate sampling trips, to give a general indication of water conditions during sample collection.

Table 3. Water-quality properties and stream discharge measured in Anchorage creeks during duplicate sampling, 1998

$\left[{ }^{\circ} \mathrm{C}\right.$, degree Celsius; $\mu \mathrm{S} / \mathrm{cm}$, microsiemen per centimeter at 25 degrees Celsius; $\mathrm{mg} / \mathrm{L}$, milligrams per liter; $\mathrm{ft}^{3} / \mathrm{s}$, cubic feet per second]

\begin{tabular}{llccccc}
\hline & Date & \multicolumn{5}{c}{ Water-quality properties } \\
\cline { 3 - 6 } & & $\begin{array}{c}\text { Temperature } \\
\left({ }^{\circ} \mathrm{C}\right)\end{array}$ & $\mathrm{pH}$ & $\begin{array}{c}\text { Specific } \\
\text { conductance } \\
(\mu \mathrm{S} / \mathrm{cm})\end{array}$ & $\begin{array}{c}\text { Dissolved } \\
\text { oxygen } \\
(\mathrm{mg} / \mathrm{L})\end{array}$ & $\begin{array}{c}\text { Discharge } \\
\left(\mathrm{ft}^{3} / \mathrm{s}\right)\end{array}$ \\
\hline Ship Creek & September 4 & 8.9 & 8.1 & 169 & 13.5 & \\
Chester Creek & September 4 & 6.6 & 8.1 & 129 & 12.8 & 4.1 \\
Campbell Creek & August 28 & 4.0 & 7.5 & 136 & 12.8 & 20 \\
Rabbit Creek & August 28 & 3.5 & 6.9 & 64 & 12.7 & 22 \\
Little Rabbit Creek & August 28 & 3.5 & 7.7 & 100 & 12.9 & 5.3 \\
\hline
\end{tabular}


Generally, fecal coliform concentrations determined from duplicate samples were similar to those in the routine samples (table 2). For example, duplicate samples collected at Chester Creek and Rabbit Creek differed by only a few colonies, and at Ship Creek and Campbell Creek they were exactly the same.

Municipality of Anchorage data from 1988-92 show that fecal coliform concentrations were generally higher during the months of August and September than annual concentration values (table 1). With the exception of Little Rabbit Creek, concentrations measured in the 1998 study were much lower than those reported in prior years (tables 1 and 2). The temporal variability at most sites, however, is 1 to 2 orders of magnitude. Larger data sets over longer periods of time are necessary to define long-term trends at the sites described in this report.

\section{REFERENCES CITED}

Alaska Department of Environmental Conservation, 1992, Section 303(d) List of water quality-limited waterbodies: Alaska Department of Environmental Conservation Air and Water Quality Division.

Alaska Department of Environmental Conservation, 1998, Section 303(d) List of water quality-limited waterbodies: Alaska Department of Environmental Conservation Air and Water Quality Division.
Alaska Department of Environmental Conservation, 1999, Water-quality standards, 18 AAC 70, as amended through May 27, 1999: Accessed on May 28, 1999 at http://www.state.ak.us/local/akpages/ ENV.CONSERV/title18/title18.htm

American Public Health Association, American W/ater Works Association, and Water Pollution Ccntrol Federation, 1992, Standard methods for the eramination of water and wastewater $\left(18^{\text {th }}\right.$ ed.): Paltimore, Victor Graphics, Inc.

Brabets, T.P., 1987, Quantity and quality of urban r'noff from the Chester Creek basin, Anchorage, Al-ska: U.S. Geological Survey Water-Resources Investigations Report 86-4312, 58 p.

Brabets, T.P., and Wittenberg, L.A., 1983, Surface-water quality in the Campbell Creek basin, Anchorage, Alaska: U.S. Geological Survey Water-Resoxrces Investigations Report 83-496, 28 p.

James M. Montgomery, Consulting Engineers, Inc., 1990, Water quality monitoring program, 1989/90 annual report for Municipality of Anchorage, Department of Health and Human Services: available from Municipality of Anchorage, Department of Health and Human Services, variously pagir ated.

Montgomery Watson (in association with HDR Engineering, Inc.), 1993, Areawide water quality monitoring program 1988-1992 interpretive renort: Report prepared for the Municipality of Anchcrage.

Myers, D.N., and Wilde, F.D., eds., 1997, National field manual for the collection of water-quality dataBiological indicators: U.S. Geological Survey Techniques of Water-Resources Investigation, book 9, chapter A7, variously paginated.

U.S. Environmental Protection Agency, 1977, Quality criteria for water, 1976: U.S. Government Printing Office, $256 \mathrm{p}$. 